\title{
Efficiency Evaluation and Influencing Factors of Government Financial Expenditure on Environmental Protection: An SBM Super-efficiency Model Based on Undesired Outputs
}

\section{Ocena efektywności i czynniki wpływające na rządowe wy- datki finansowe na ochronę środowiska: model Super-efektywności SBM oparty na niepożądanych efektach}

\author{
Su Jialu*, Ma Zhiqiang ${ }^{\star *}$, Li Mingxing ${ }^{\star * *}$, \\ Fredrick Oteng Agyeman ${ }^{\star \star \star \star}$, Zhu Yue ${ }^{\star \star \star \star \star}$
}

\author{
School of Management, Jiangsu University, Zhenjiang 212013, P.R. China \\ *E-mail:870900521@qq.com, ORCID:0000-0002-2231-3273 \\ **E-mail:mzq@ujs.edu.cn,ORCID:0000-0002-6492-0733 \\ ***E-mail (Corresponding Author): mingxingli6@163.com, ORCID: 0000-0002-4039-5997, \\ ****E-mail: fredrickotengagyeman2@gmail.com, ORCID:0000-0003-4615-2555 \\ *****Email: 1821577663@qq.com, ORCID:0000-0002-2111-8580
}

\begin{abstract}
In recent years, the adoption of the precise approach for coordinating socio-economic growth and environmental protection to attain sustainable development has become an urgent challenge to be addressed in China. The current development of environmental governance and the efficiency of government financial expenditure on environmental protection (EPEE) deserves enormous attention. With the aid of the provincial panel data, this study emphasized on the use of the SBM super-efficiency model based on unexpected output to quantify the efficiency of China's government expenditure on environmental protection from 2013-2018 and constructed the Ordinary Least Squares (OLS) regression model to investigate the influencing factors of the government expenditure on environmental protection. The results of the efficiency measurement portray that the aggregate EPEE in China is unsatisfactory. The efficiency value for the western region is greater than that of the central and eastern regions, while the values obtained from the eastern region are above that of the central region. Population size and urbanization level have negative implications on the efficiency value, while the regional economic development level positively promotes the efficiency of the government expenditure on environmental protection. Finally, the corresponding countermeasures and suggestions for policy implementation are outlined accordingly.
\end{abstract}

Key words: the efficiency of government expenditure on environmental protection, unexpected output, SBM super-efficiency model, influence factor

\section{Streszczenie}

W ostatnich latach przyjęcie precyzyjnego podejścia do koordynacji wzrostu społeczno-gospodarczego i ochrony środowiska w celu osiągnięcia zrównoważonego rozwoju stało się pilnym zadaniem w Chinach. Na ogromną uwagę zasługuje obecny rozwój zarządzania środowiskiem oraz efektywność rządowych nakładów finansowych na ochronę środowiska (EPEE). Z pomocą danych panelowych z prowincji, badanie to kładło nacisk na wykorzystanie modelu super-wydajności SBM opartego na nieoczekiwanych wynikach do ilościowego określenia wydajności chińskich wydatków rządowych na ochronę środowiska w latach 2013-2018. Skonstruowano kwadraty (OLS) modelu regresji do badania czynników wpływających na wydatki rządowe na ochronę środowiska. Wyniki pomiaru efektywności pokazują, że zagregowany EPEE w Chinach jest niezadowalający. Wartość efektywności dla regionu zachodniego jest większa niż w regionach centralnych i wschodnich, podczas gdy wartości uzyskane 
z regionu wschodniego są wyższe niż w regionie centralnym. Negatywnie na wartość efektywności wpływa wielkość populacji i poziom urbanizacji, natomiast regionalny poziom rozwoju gospodarczego pozytywnie wpływa na efektywność wydatków rządowych na ochronę środowiska. Na koniec nakreślono możliwe sposoby poprawy sytuacji i sugestie dotyczące wdrażania polityki.

Słowa kluczowe: efektywność wydatków rządowych na ochronę środowiska, nieoczekiwane wyniki, model super-efektywności SBM, współczynnik wpływu

\section{Introduction}

Since the introduction of the Chinese reform and opening up in 1978, the Chinese economy has been characterized by rapid development. Currently, China has been positioned as the second-largest economy in the globe, and it is playing an influential role in the world. Nevertheless, with the rapid growth of the Chinese economy, it has been bedevilled with heavy environmental costs to be paid accordingly. The extensive method of economic growth has increasingly led to huge environmental problems and brought severe challenges to sustainable development policies in China and other countries.

Recently, several countries have progressively attached great importance to the enormous impact of environmental problems such as climate change on human beings and actively held relevant international conferences, which have greatly contributed to improving the environment. United Nations conference on world environmental conventions held in Paris in May 2019 attracted the government of China to attach great importance to environmental governance and protection issues, and have taken a series of measures and formulated relevant policies to promote China's deep participation in global environmental governance actively. The policies implemented are evidenced in the 17 th, 18 th, and 19th annual National Congress of the Communist Party of China (CPC), respectively postulating the basic national policies of saving resources and protecting the environment, promoting the construction of ecological civilization and increasing the protection of the ecological environment, and solving outstanding environmental problems. Besides the central government initiatives, the provincial governments have also made positive contributions. The Jiangsu provincial government thoroughly studied and implemented the policy of the recent 19th National Congress of CPC, and issued the implementation suggestions on strengthening the ecological environment protection plans in an all-round way and resolutely pursuing pollution prevention and control, which put forward important measures to promote the highquality development of Jiangsu's ecological environment and build a new Jiangsu which is strong, rich, beautiful and civilized.

The externality of environmental problems, the public good approach of environmental quality, and fuzzy property rights of environmental resources have led to market failure in the field of environmen- tal economies, that is, the excessive use of environmental resources and insufficient supply of environmental treatment policy needs urgent government intervention to solve environmental pollution problems (Siebert \& Siebert, 1998). The government expenditures on environmental protection are a vital protection measure for government intervention in environmental governance, and the efficiency of the government disbursement on environmental protection reflects the effectiveness of environmental governance and its improvement (Halkos \& Paizanos, 2013; Kuai et al., 2019; Xu \& Hu, 2020). Recently, the issue of how to coordinate economic growth and environmental protection to achieve sustainable development has been prioritized in China. As people progressively pay attention to environmental protection, it is expected that the government attaches great importance to the efficient utilization of the government expenditure on environmental protection.

Therefore, this study uses the inter-provincial panel data and the SBM super-efficiency model based on the unexpected output to measure and analyze the efficiency of government expenditure on environmental protection (EPEE) from 2013 to 2018, and then empirically investigate the influencing factors of EPEE based on OLS regression model, and puts forward corresponding countermeasures and suggestions for policy implementation to promote the efficient use of the government expenditure on environmental protection, and to promote the sustainable development process in China continuously.

\section{Literature Review}

The Data Envelopment Analysis (DEA), propounded by (Charnes et al., 1978), has been widely applied in measuring the EPEE. Also, (Biao, 2012; Wang, 2018; Zhang et al., 2019), used the DEA model to examine the EPEE in China. Their results indicated that the EPEE value obtained in the western region exceeds the eastern and central regions, which are in unison with the study results (Wang, B.; Liu, J., 2011). Conversely, a different conclusion was drawn by (Huang, 2011) suggesting that the DEA-SBM model applied to the EPEE in 30 designated provinces pointed out th-at the efficiency in the economically developed eastern region is generally greater than that of central and western regions. (Zhu et al., 2014) also used the DEA model to measure the efficient use of government expenditure concerning environmental protection and concluded that the efficiency of eastern and western provinces is congru- 
ent but higher than that of central provinces. To add, (Sun, K.; Sun, 2016) used the data of the government expenditure on environmental protection in the Jilin Province, China and evaluated the EPEE in eight prefecture-level cities in Jilin Province using a twostage DEA model, with an empirical analysis on the factors affecting the EPEE in each city with restricted dependent variables. The results indicated that the efficiency level of municipal governments is incongruent and should be greatly improved.

When using the DEA model, it is necessary to consider the evaluation index system of EPEE. Concerning the selection of input indicators, there is no doubt that much attention is given to financial, environmental protection expenditure. However, there is no uniform standard for the selection of output indicators. Most scholars enumerate the industrial three wastes (aggregate amount of industrial waste gas discharge, the aggregate amount of industrial wastewater discharge, and the aggregate yield of the industrial solid waste) as the main output indicators (Hongguo, 2015; Yongbin, 2015). (Cheng, C.; Chen, 2017) determining output indicators from three dimensions: local environmental pollution degree (total wastewater discharge, sulfur dioxide discharge), the local environmental governance capacity (domestic garbage removal), and the local environmental governance result (artificial afforestation area in that year).

In identifying the factors affecting the efficiency of government expenditure on environmental protection, (Dasgupta et al., 2002; Zhao, J.; Li, S.; Wang, 2020) revealed that the number of residents' complaints about environmental pollution depends on the government's emphasis on environmental pollution control, and the more complaints there are, the better the efficiency of government environmental protection. (Krajewski, 2016) depicted that there is a significant positive relationship between economic growth and government environmental protection expenditure. Moreover, an examination of the Tobit model to analyze the influencing factors of the EPEE depicted that government decentralization, regional economic development level, industrialization degree, and population size have negative effects on the EPEE, while population and education level have significant positive effects on the EPEE (Wang, Q.; $\mathrm{Li}, 2018$ ).

Furthermore, (Amankwah-Amoah \& Syllias, 2020) analyzed environmental sustainability initiatives and found that fostering environmental sustainability involves demonstrating concern for the environment and seeking to minimize environmental waste, resource depletion, pollution, and emissions that lead to enormous financial expenditure on resources. Reducing the environmental footprint of organizations through the adoption of measures such as Research and development, recycling, waste reduction, redesigning production and delivery systems, and incorporating environmentally friendly raw materials in the production stages will minimize financial expenditure and carbon emissions (Aguilar-Hernandez et al., 2021; Petrović \& Lobanov, 2020; Zafar et al., 2019). Therefore, the evaluation of the efficiency of China's government expenditure on environmental protection is of great significance

To sum up, it is evidenced that a lot of domestic and foreign scholars have conducted in-depth research on the efficient utilization of the government expenditure on environmental protection, which has laid a solid research foundation for this paper, but there are still the following limitations that this seeks to address. To begin with, the measurement methods adopted by earlier scholars are relatively simple, without considering the slack part of efficiency and unexpected output. To add, the evaluation index system needs to be further improved. Again, the data used cannot be updated in time, making it difficult to reflect the new trend of the efficiency of Chinese government expenditure on environmental protection in recent years. Concerning these reasons enumerated, this study used the SBM super-efficiency model based on unexpected output and used six consecutive years of data from China as the research sample to measure the efficient use of the provincial governments' financial expenditure concerning environmental protection, and explore its impacting factors, to provide countermeasures and suggestions for promoting the EPEE in China, and to enrich the research knowledge in related fields.

\section{Materials and Methods}

\subsection{The SBM Super-Efficiency Model of Unexpected Output}

Data Envelopment Analysis (DEA) is widely applied to the efficiency measurement of the public sectors and Mathematical Economics because it can effectively eliminate statistical errors (Ahn et al., 1988; Farrell, 1957). DEA is a quantitative analysis method to investigate the relative effectiveness of comparable units of the same characteristics using the linear programming method according to the multiple input and output indicators. The basic DEA models are divided into two categories: the CCR model based on the constant return on the scale and the BCC model based on variable return on the scale, both of which are radial angles. Concerning the radial DEA model, the relaxation improvement is not reflected in the measurement of the radial distance efficiency value, (Tone, 2001) defined the SBM model as (Slacks-based Measure) to overcome the problem of variable relaxation in 2001. However, this model cannot further evaluate multiple decisionmaking units (DMUs) to distinguish their efficiency values. To rectify this defect, (Tone, 2002) proposed the use of the SBM super-efficiency model described as more complicated and not just an increase of the restriction condition of $j \neq k$. The super-efficiency value of effective DMUs is often considered to be 
greater than 1 so that effective DMU can be distinguished. SBM super-efficiency is only applicable to effective DMU. For SBM effective DMU $k$, its nonoriented constant return to scale to SBM super-efficiency model is expressed as follows:

$$
\begin{aligned}
\min \rho_{S E} & =\frac{\frac{1}{m} \sum_{i=1}^{m} \bar{x}_{i} / X_{i k}}{\frac{1}{S} \sum_{r=1}^{s} \bar{y} / y_{r k}} \\
\text { s.t. } \bar{x}_{i} \geq & =\sum_{j=1, j \neq k}^{n} x_{i j} \lambda_{j} \\
\bar{y}_{r} \leq & \sum_{j=1, j \neq k}^{n} y_{r j} \lambda_{j}
\end{aligned}
$$$$
i=1,2 \ldots, m ; r=1,2 \ldots, q ; j=1,2 \ldots, n(j \neq k)
$$

Where the effective production possibilities that can be constructed by the DMUs other than DMU $k$ are described as:

$$
\left\{(x, y): x \geq \sum_{j=1, j \neq k}^{n} x_{i j} \lambda_{j}, y \leq \sum_{j=1, j \neq k}^{n} y_{r j} \lambda_{j}\right\}
$$

The projected value of $(\bar{x}, \bar{y})$ of the evaluated DMU of $k$ in the SBM super-efficiency is the optimal solution of the model.

Again, (Tone, 2002) did not give the projected formula of the SBM super-efficiency model with unexpected output, so (Cheng, 2014) improved on the model and restructured the SBM super-efficiency model with unexpected output as follows:

$$
\min \rho
$$

$$
\begin{aligned}
& =\frac{1+\frac{1}{m} \Sigma_{i=1}^{m} s_{i}^{-} / X_{i k}}{1-\frac{1}{q_{1}+q_{2}}\left(\Sigma_{r=1}^{q_{1}} S_{r}^{+} / y_{r k}+\Sigma_{t=1}^{q_{2}} S_{t}^{b-} / b_{t k}\right)} \\
& \text { s.t. } \sum_{j=1, j \neq k}^{n} x_{i j} \lambda_{j-s_{i}^{-} \leq x_{i k}} \\
& \sum_{j=1, j \neq k}^{n} y_{r j} \lambda_{j}+s_{r}^{+} \geq y_{r k} \\
& \sum_{j=1, j \neq k}^{n} b_{t j} \lambda_{j}-s_{t}^{b-} \leq b_{t k} \\
& 1-\frac{1}{q_{1}+q_{2}}\left(\sum_{r=1}^{q_{1}} s_{r}^{+} / y_{r k}+\sum_{t=1}^{q_{2}} s_{t}^{b-} / b_{t k}\right)>0 \\
& \lambda, s^{-}, s^{+} \geq 0
\end{aligned}
$$

$$
i=1,2 \ldots, m ; r=1,2 \ldots, q ; j=1,2 \ldots, n(j \neq k)
$$

Where the added constraint

$$
1-\frac{1}{q_{1}+q_{2}}\left(\sum_{r=1}^{q_{1}} s_{r}^{+} / y_{r k}+\sum_{t=1}^{q_{2}} s_{t}^{b-} / b_{t k}\right)>0
$$

can be eliminated during linear conversion. The DEA model for undesired output can be expressed as a negative number.

\subsection{Indicators Selection and Data Sources}

In this study, the efficiency of government financial expenditure on environmental protection in 30 designated provinces (municipalities and autonomous regions) is taken as the research object. However, data inadequacy concerning Tibet in China was not included in the research scope. To compare the effi- ciency values among regions, 30 provinces (municipalities and autonomous regions) are categorized into eastern, central, and western regions according to their geographical location. The eastern region comprises 11 provinces and cities (Beijing, Tianjin, Hebei, Liaoning, Shanghai, Jiangsu, Zhejiang, Fujian, Shandong, Guangdong, and Hainan). The central region is also made up of 8 provinces (Shanxi, Jilin, Heilongjiang, Anhui, Jiangxi, Henan, Hubei, Hunan). And finally, the western region is also made up of 11 provinces, cities, and autonomous regions (Sichuan, Chongqing, Guizhou, Yunnan, Shaanxi, Gansu, Qinghai, Ningxia, Xinjiang, Guangxi, and Inner Mongolia). This study selected the period spanning 2013-2018 for the analysis.

By drawing lessons from the previous studies and further considering the availability and authenticity of data, the input index selected for measuring the efficiency of the government expenditure on environmental protection in this study is the government expenditure on environmental protection of provinces (municipalities and autonomous regions) in each year, and the output index was selected from three dimensions, namely, environmental pollution reduction, environmental pollution control, and ecological environment quality. The wastewater discharge, the sulfur dioxide discharge, and the industrial solid waste production were selected as indicators to measure environmental pollution reduction. While the comprehensive utilization of industrial solid waste and the harmless treatment rate of domestic garbage are selected as indicators to measure environmental pollution control. The artificial afforestation area and green coverage rate of the built-up area within the period were also selected as indicators to measure ecological environment quality. Among them are wastewater discharge, sulphur dioxide discharge, and industrial solid waste production are undesirable output indicators. All the selected data used to analyze the variables in this study were collected from the China Statistical Yearbook 2014-2019.

\section{Estimation Results and Discussion}

\subsection{Efficiency Value Analysis}

In this study, the SBM super-efficiency model based on unexpected output is selected to quantify the efficiency of the government expenditure on environmental protection (EPEE) in the selected 30 provinces (municipalities and autonomous regions), and an in-depth analysis is carried out from the national level, the regional level, and the provincial level respectively. The estimation results obtained are shown in Table 1.

\section{1) Analysis of the national-level}

Table 1 reports the EPEE of 30 provinces from 2013 to 2018. It indicates the calculation of the average efficiency values of the selected provinces (munici- 
Table 1. The EPEE in China from 2013 to 2018

\begin{tabular}{|c|c|c|c|c|c|c|c|c|}
\hline & 2013 & 2014 & 2015 & 2016 & 2017 & 2018 & $\begin{array}{l}\text { Mean } \\
\text { value for } \\
\text { six years }\end{array}$ & $\begin{array}{l}\text { National } \\
\text { ranking }\end{array}$ \\
\hline Beijing & 1.020 & 1.037 & 1.011 & 1.008 & 1.047 & 1.145 & 1.045 & 4 \\
\hline Tianjin & 1.016 & 1.019 & 1.015 & 1.020 & 1.023 & 1.045 & 1.023 & 8 \\
\hline Hebei & 0.447 & 0.431 & 0.450 & 0.613 & 0.405 & 1.010 & 0.559 & 24 \\
\hline Liaoning & 0.518 & 0.482 & 0.487 & 0.724 & 0.631 & 1.009 & 0.642 & 20 \\
\hline Shanghai & 1.003 & 1.005 & 1.003 & 0.361 & 1.098 & 1.098 & 0.928 & 14 \\
\hline Jiangsu & 1.004 & 1.002 & 1.002 & 1.001 & 1.001 & 0.563 & 0.928 & 13 \\
\hline Zhejiang & 0.641 & 0.457 & 0.536 & 0.504 & 0.505 & 0.376 & 0.503 & 27 \\
\hline Fujian & 1.029 & 0.777 & 0.501 & 0.238 & 0.233 & 0.260 & 0.506 & 26 \\
\hline Shandong & 1.008 & 1.013 & 1.039 & 0.690 & 1.014 & 1.005 & 0.962 & 11 \\
\hline Guangdong & 0.202 & 0.313 & 0.360 & 0.436 & 0.220 & 0.205 & 0.289 & 29 \\
\hline Hainan & 1.303 & 1.312 & 1.322 & 1.296 & 1.274 & 1.233 & 1.290 & 1 \\
\hline Mean values of eastern region & 0.835 & 0.804 & 0.793 & 0.717 & 0.768 & 0.814 & 0.789 & - \\
\hline Shanxi & 1.081 & 1.094 & 1.100 & 1.057 & 1.002 & 0.875 & 1.035 & 6 \\
\hline Jilin & 0.237 & 0.383 & 0.435 & 0.397 & 0.348 & 0.469 & 0.378 & 28 \\
\hline Heilongjiang & 0.280 & 0.253 & 0.316 & 0.327 & 0.173 & 0.327 & 0.279 & 30 \\
\hline Anhui & 1.015 & 1.040 & 1.048 & 1.036 & 1.035 & 1.035 & 1.035 & 7 \\
\hline Jiangxi & 0.668 & 0.780 & 0.729 & 0.502 & 0.364 & 0.428 & 0.578 & 23 \\
\hline Henan & 0.642 & 0.712 & 0.548 & 0.543 & 0.600 & 0.484 & 0.588 & 21 \\
\hline Hubei & 0.578 & 0.832 & 0.501 & 0.561 & 0.517 & 0.498 & 0.581 & 22 \\
\hline Hunan & 0.424 & 1.010 & 0.516 & 1.009 & 1.036 & 1.062 & 0.843 & 16 \\
\hline Mean values of central region & 0.616 & 0.763 & 0.649 & 0.679 & 0.634 & 0.647 & 0.665 & - \\
\hline Sichuan & 0.217 & 0.210 & 0.476 & 0.760 & 1.023 & 0.556 & 0.540 & 25 \\
\hline Chongqing & 1.080 & 1.066 & 1.045 & 1.017 & 1.014 & 1.038 & 1.043 & 5 \\
\hline Guizhou & 1.012 & 1.026 & 1.054 & 0.703 & 1.081 & 1.062 & 0.990 & 9 \\
\hline Yunnan & 1.094 & 1.061 & 1.043 & 0.723 & 0.418 & 1.019 & 0.893 & 15 \\
\hline Shanxi & 0.720 & 1.011 & 0.566 & 1.002 & 0.342 & 0.587 & 0.705 & 18 \\
\hline Gansu & 0.458 & 1.018 & 1.057 & 1.088 & 1.042 & 1.085 & 0.958 & 12 \\
\hline Qinghai & 1.254 & 1.243 & 1.279 & 1.198 & 1.244 & 1.366 & 1.264 & 2 \\
\hline Ningxia & 1.066 & 1.099 & 1.064 & 1.175 & 1.061 & 1.094 & 1.093 & 3 \\
\hline Xinjiang & 0.563 & 0.621 & 0.795 & 0.826 & 1.101 & 1.017 & 0.821 & 17 \\
\hline Guangxi & 0.762 & 0.584 & 0.545 & 0.745 & 0.568 & 0.759 & 0.661 & 19 \\
\hline Inner Mongolia & 1.019 & 1.049 & 1.017 & 1.027 & 0.730 & 1.037 & 0.980 & 10 \\
\hline Mean values of western region & 0.840 & 0.908 & 0.904 & 0.933 & 0.875 & 0.966 & 0.904 & - \\
\hline Overall mean value & 0.779 & 0.831 & 0.795 & 0.786 & 0.772 & 0.825 & 0.798 & - \\
\hline
\end{tabular}

palities and autonomous regions) with their respective nationally ranked values. The initial 8 provinces include (municipalities and autonomous regions) whose efficiency value is greater than 1 , accounting for $26.67 \%$, and the remaining $73.33 \%$ are ineffective decision-making units. This portrays that the aggregate efficiency of China's EPEE is below par. The positive effect of the government expenditure on environmental protection is not harmonized with the rapid growth of environmental expenditure, which serves as the motivation and key focus of this study. In the subsequent sections, the researchers analyzed the changing trend of EPEE in China.

First of all, the change of the overall mean value from 2013 to 2018, as shown in Figure 1 below, depicts that it is in a relatively fluctuating state. The dynamic trend of the efficiency value experienced continual fluctuation until the end of the period. Secondly, by observing the values obtained for each year, the researchers identified that the mean efficiency value of each year never reached the effective Decision-Making Unit (DMU); however, the results obtained were greater than 0.77 . This demonstrates that, though there is an excess of government environmental protection expenditure in China, however, it fails to make maximum utilization of the government environmental protection expenditure assigned to reach the most effective utilization state. Again, the utilization rate is still at the intermediate stage, and there is an expectation of great improvement to be achieved in the successive periods. Finally, the maximum efficiency value rose to $(0.831)$ in 2014 and then decreased in succeeding years. But the decline of the efficiency value was not huge; the lowest value reached (0.772) in 2017. The disparities between the maximum and minimum values were only 0.059. Through the analysis of the relevant policies implemented by the Chinese government, the researchers found that in 2013 China issued the Air Pollution Prevention and Control Action, which took effect in 2014, and the measures implemented produced a positive result, thus promoting the efficient utilization of the government expenditure on environmental protection in 2014. Based on the afore- 


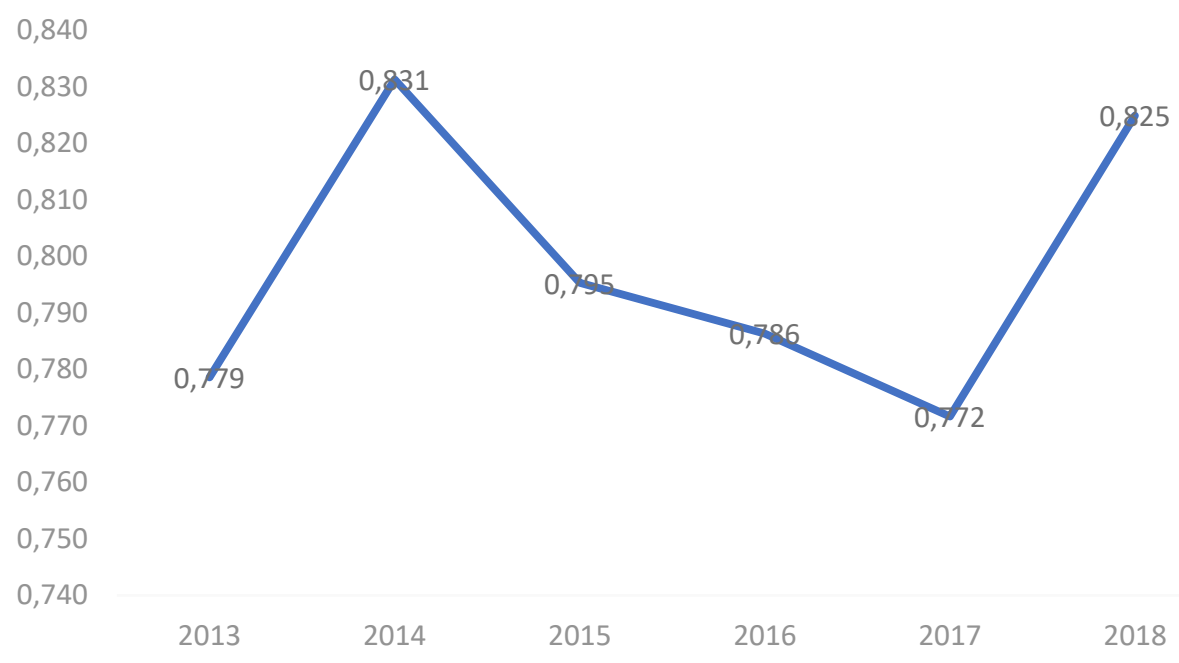

Figure 1. The changing trend of the overall mean value of EPEE from 2013 to 2018 in China

mentioned, water pollution prevention and soil pollution remediation policies were implemented in 2014. All the designated provinces (municipalities and autonomous regions) increased the financial expenditure on environmental protection. However, compared with air pollution treatment, water pollution prevention, and soil remediation, results are difficult to achieve in a short time. Therefore the efficiency value was projected to decline in the preceding years. Contrarily, it rose again in 2018. The central government of China has been playing a leading role in terms of environmental governance, with the vision that the development of the environmental protection sector depends on the change of government policies to a great extent. Suppose the Chinese government pursue the policy of attaining efficiency of the government expenditure on environmental protection to reach an effective unit. In that case, it must follow the operating standards of the market economy, optimize the allocation of resources through effective policy measures, and make every effort to promote environmental protection in China.

\section{(2) Analysis of the regional level}

The study selected 30 provinces (municipalities and autonomous regions) and apportioned them into the eastern region, the central region, and the western region, as shown in Figure 2 with an indication of the change in the trend of each region's efficiency value. From the analysis of Table 1 and Figure 2, it can be deduced that from 2013 to 2018, the efficiency values of all the regions showed a dynamic fluctuation trend. Specifically, the fluctuation trend of the western region displayed an upward trend; the eastern region showed a downward trend at the initial stage and climbed up, while the central region showed a downward trend at some point. It can be intuitively found from Figure 2 that the efficiency value of the western region is greater than that of the central and eastern regions, while the eastern region is slightly higher than that of the central region. Two main rea- sons contributed to this phenomenon: one is the difference in developmental stages between regions, and the other is the gradual transfer of industries to inland areas in recent years. As far as the western provinces are concerned (municipalities and autonomous regions), most provinces have less developed industrial facilities, and tourism has become the key development industry.

Ecological construction, such as returning farmland to forests, protecting natural forests, and harnessing wind and sand sources, has further promoted the efficient utilization of government expenditure on environmental protection in China's western region. Put differently, the difference in industrialization degree among the three regions directly influences the difference in pollution emission and governance level, which is reflected in the level of efficiency and the use of government and environmental protection expenditures. Concurrently, the industrial transfer in recent years, especially the inland migration of the manufacturing industry, not only relieves the environmental pressure in the eastern region but also increases the environmental pressure in the central region, resulting in the lower efficiency utilization of government environmental protection expenditure in the central region than in the eastern and western region of China. Generally speaking, although there are differences in the level of efficiency in the use of government environmental protection expenditures among the three regions, the differences are not widely significant, and they are currently showing a trend of catching up with each other.

\section{(3) Analysis of provincial level}

Figure 3 shows the mean value of each province (municipalities and autonomous regions) from 2013 through 2018. Analysis from Table 1 and Figure 3 indicate the top five provinces (municipalities and autonomous regions) with the highest average efficiency values: Hainan (1.290), Qinghai (1.264), Ningxia (1.093), Beijing (1.045), and Chongqing 


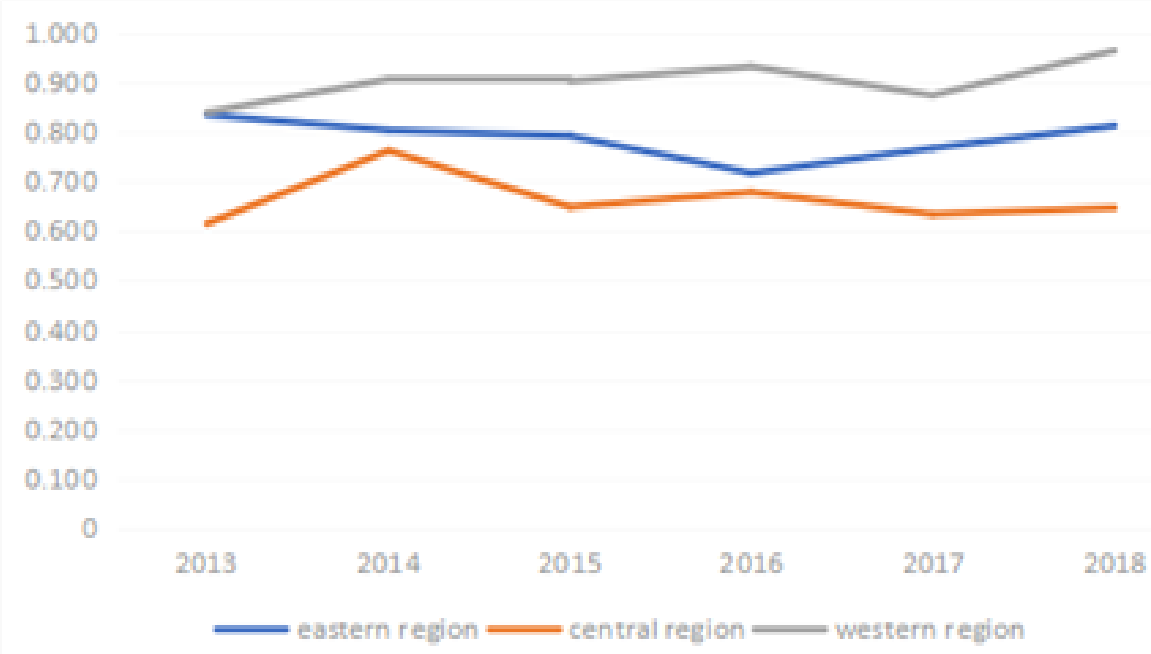

Figure 2. The changing trend of the EPEE in various regions

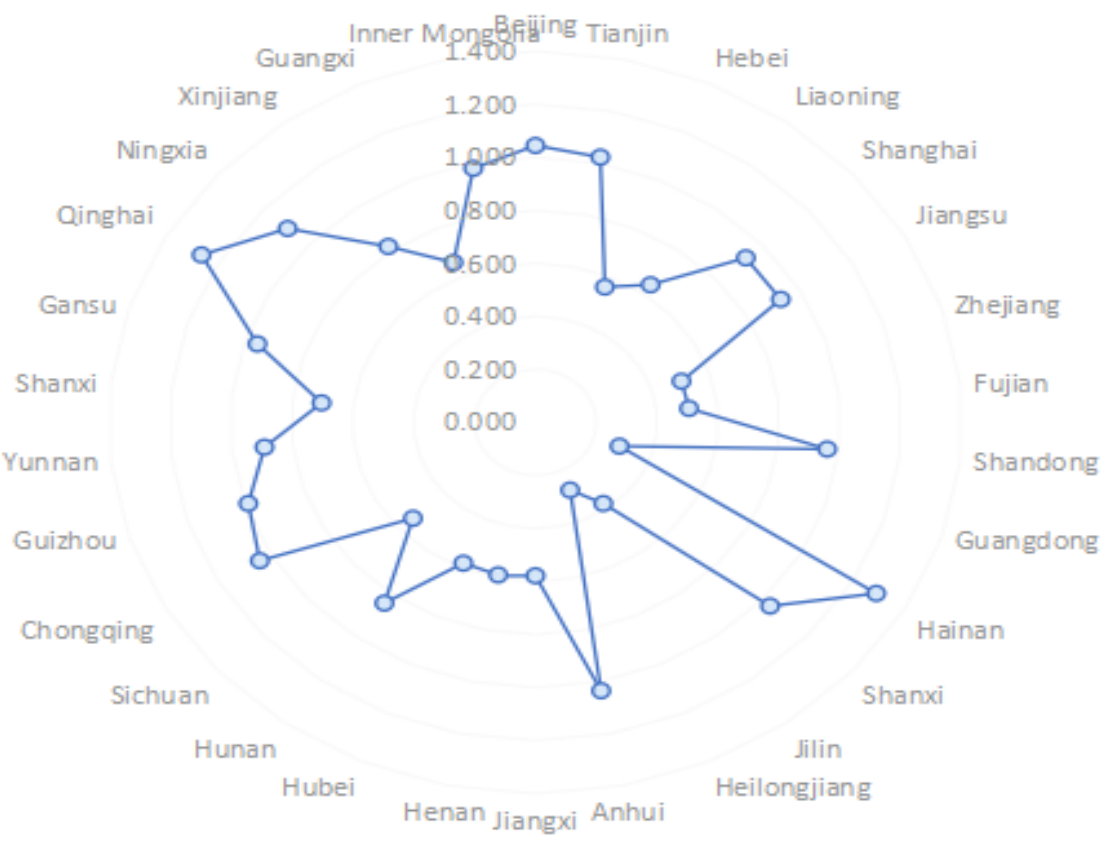

Figure 3. The EPEE of the 30 provinces (municipalities and autonomous regions)

(1.043), all of which are greater than 1. It is not weird to find that the top three provinces (autonomous regions) have the following common characteristics. Firstly, the population size of these three regions isrelatively small, all of which are less than 10 million people, so they occupy a significant portion of pollution emissions. Secondly, these areas focus on the development of tourism, with pleasant climate and scenery, supplemented by the government's strong support and the gradual improvement of transportation system which attracts a large number of indigene and foreign nationals in recent years. In particular, Hainan Province, which ranks first, is vigorously developing the tourism industry, often referred to as the smokeless industry, which has reduced the pollution impact on the environment. From the period the State Council of the People's Republic of
China issued the Opinions on Promoting the Construction and Development of the Hainan International Tourism Island in the year 2010, the local government has regarded it as a major strategic plan and has paid full attention to the coordinated development of regional economy and the environment, and made efforts to initially put up a world-class island leisure resort in the year 2020. Although Ningxia is an economically underdeveloped region, the autonomous regional government has invested a lot of funds to enhance the progress of environmental protection in recent years. In 2018, Ningxia's government environmental protection expenditure accounted for $1.94 \%$ of GDP, significantly higher than the figure $1.27 \%$ obtained in 2013. Simultaneously, the autonomous region's government has strengthened supervision, thus promoting the efficient utili- 
zation of government expenditure on environmental protection. The fourth and the fifth places are Beijing and Chongqing, respectively. Compared with some bigger provinces, it was realized that the municipalities that are directly under the central government are more convenient and centralized in terms of management, and their policies are better implemented. Concurrently, the implementation of environmental protection policies in these two regions is more accurate and efficient. As an illustration, Chongqing promulgated the Chongqing Environmental Protection Regulations and implemented unique environmental protection policies that fully use its constraints and benefits. As the political center of China, Beijing is even more aggressive in implementing environmental protection policies, giving full attention to the government's vision. In March 2020, Beijing issued the first internal regulation of the Communist Party in ecological, environmental protection, which put forward disciplinary requirements for the inspected projects and regulated and restrained the ecological, environmental protection inspection teams and directors.

The three bottommost provinces are Jilin, Guangdong, and Heilongjiang, among which Heilongjiang has the lowest average efficiency value (0.279). Guangdong also has low efficiency due to excessive capital investment and a large population as an economically developed province. The large size of the population base directly leads to an increase in supervision difficulty. Although the government has invested a lot of capital, it is difficult to attain efficiency, resulting in a waste of financial expenditure in various fields where supervision is cumbersome. The net effect is low efficiency. Jilin and Heilongjiang belong to the three northeastern provincesformer heavy industrial bases. Since the reform and opening-up policy was implemented in 1978, the coastal provinces and cities (such as Shanghai, Jiangsu, and Zhejiang) have achieved remarkable development as compared with the provinces along the prosperous Yangtze River Delta region, the development of Northeastern China, where heavy industry is concentrated, lags obviously.

It is evidenced that, for long periods, the three northeastern provinces did not place much emphasis on the development of light and tertiary industries, which led to the imbalance of industrial structure and paid a heavy environmental cost. The environmental problems keep accumulating over the years, and the backwardness of economic development directly leads to the inefficient use of the government expenditure on environmental protection in the Jilin and Heilongjiang provinces. Recently, the vision of promoting and revitalizing old industrial bases, vigorously developing the economy, and implementing environmental protection policy is key to the province. The Chinese Central Government and the local governments of the three northeastern provinces have taken active measures to strengthen environ- mental protection and governance. The environmental protection work in the three northeastern provinces has been strengthened, and the environmental deterioration menace has been curbed. However, it will take time to catch up with the other advanced provinces (municipalities and autonomous regions).

\subsection{Analysis of Influencing Factors}

The EPEE in 30 provinces is measured by adopting the super-efficiency SBM model based on the unexpected output spanning the period 2013 to 2018 . The analysis of this study includes a regression model to analyze the influencing factors further. In most previous studies, because the maximum efficiency value of 1 is considered to be the truncated value, most works of literature used the Tobit regression model. However, there is no truncation problem of efficiency value in terms of super efficiency, and it is not prudent to adopt a special Tobit of regression model to deal with truncated value. Therefore, this paper constructs the OLS model to analyze the influencing factors in detail.

By considering the available data, this study takes the EPEE as a dependent variable and takes population size (pop), regional economic development level (gdp), urbanization level (urban), industrialization level (indu), and population education level (edu) as independent variables. Regarding the acquisition of index data, this paper measures the population size via the aggregate population at the end of the year, measures the level of regional economic development via regional GDP, measures the urbanization level through the proportion of the urban population to the aggregate population at the end of the year, it also measures the degree of industrialization through the proportion of the value-added of the secondary industry to the regional GDP, and measures the education level of the population through the proportion of students in ordinary colleges and junior colleges to the total population. All the data used were gathered from the Chinese Statistical Yearbook from 2013-2018.

Table 2. Analysis of regression results

\begin{tabular}{|l|l|l|l|l|}
\hline $\begin{array}{l}\text { Varia- } \\
\text { ble }\end{array}$ & $\begin{array}{l}\text { Coeffi- } \\
\text { cient }\end{array}$ & Sig. & $\begin{array}{l}\text { Tole- } \\
\text { rance }\end{array}$ & VIF \\
\hline pop & -0.460 & $0.000^{* * *}$ & 0.876 & 1.142 \\
\hline gdp & 0.302 & $0.098^{*}$ & 0.139 & 7.218 \\
\hline urban & -0.306 & $0.097 *$ & 0.137 & 7.317 \\
\hline indu & -0.059 & 0.415 & 0.892 & 1.122 \\
\hline edu & 0.017 & 0.821 & 0.857 & 1.167 \\
\hline
\end{tabular}

Note: significance level indicating $*$ means $\mathrm{p}<0.1$,

$* *$ means $\mathrm{p}<0.05$ and $* * *$ means $\mathrm{p}<0.01$

Table 2 presents the regression results of the factors affecting the efficient use of government expenditure on environmental protection in China. Firstly, the collinearity test is carried out by observing the tolerance and variance expansion factor (VIF) of each of the variables. It is assumed that when the tolerance is closer to 0 , or VIF is greater than or equal to 10 , it 
indicates that there may be multicollinearity among the variables. It can be observed from the table below that the tolerances of all explanatory variables are greater than 0.1 , and the VIF is lower than 7.5 , so it can be concluded that there is no multicollinearity among variables, which can be included in the regression equation.

It can be observed from Table 2 that the population size negatively affects the efficient utilization of the government expenditure on environmental protection, and the coefficient of the efficient expenditure is -0.46 , which passes the $1 \%$ significance level test. This demonstrates that the larger the population size, the lower the efficiency value. The reason may be that the population size is too large to produce a crowding effect, which leads to an increase in environmental governance costs. Besides, there is limited government investment in the field of environmental governance, and residents generally have insufficient knowledge on environmental protection policies which indirectly inhibit the growth of efficiency. For instance, areas with a large population face the difficulty of government supervision, which invariably leads to low-efficiency value.

The coefficient of the regression results obtained for the level of regional economic development and the efficiency of the government expenditure on environmental protection is significantly positive, which passes the $10 \%$ significance level test. This indicates that the higher the level of regional economic development, the higher the efficiency value. Emphasis can also be placed on Maslow's hierarchy of needs theory, which states that when the basic needs (the physiological and safety needs) are satisfied, people tend to pursue a higher level of life. Currently, with the continual growth of the economy, the expectation for people living in a specific environment and quality of life are increasing. For instance, in many firsttier cities, more and more people are willing to live in the suburbs with a better environment. Residents' expectation of environmental quality has brought gargantuan pressure to the government, thus invariably promoting the environmental governance level. Notwithstanding, the people's quality of life is generally high, and their awareness of environmental protection is relatively strong, which has played a positive role in promoting the efficient use of the government expenditure on environmental protection in economically developed areas.

Urbanization negatively affects the efficient utilization of the government expenditure on environmental protection. The coefficient of urbanization expenditure is -0.306 , which qualifies the $10 \%$ significance level test. This result portrays that the utilization rate of the environmental protection funds is generally not high in areas of rapid urbanization. Modern urbanization is described as the urbanization of migrant workers. China's transformation from the agricultural population to the non-agricultural population has increased urbanization problems. With the continuous influx of rural populations, the population scale has increased rapidly in urban areas, leading to higher resource consumption, negatively impacting the original urban functions and structures. Some external problems such as land, water shortage, atmosphere, urban noise, electromagnetic radiation, and environmental pollution have gradually emerged. Concurrently, most migrant workers are engaged in manual labor in Chinese cities. As a result, the urgent survival needs of migrant workers need to be addressed by the government, which indirectly leads to the investment impulse of local governments to a certain extent, resulting in government actions incompatible with the national environmental protection measures in China.

Theoretically, the degree of industrialization negatively affects the efficient utilization of the government expenditure on environmental protection, while the level of education affects the latter positively, but none of the effects is significant. To some extent, industrial development is the main source of environmental pollution. In areas with high industrialization levels, industrial wastes, as well as the amount of resource consumption, are the contributing factors for environmental pollution.

This study reveals that the regression coefficient of the industrialization degree is not significant. The initial reason is attributed to the Central Government of China's promotion, transformation, and upgrading of the industrial structure leading to the acceleration and transformation of economic development. The second reason is that the vigorous guidance of the Chinese Government and the active cooperation of Chinese people enhance the green and healthy development of China's industries. Hence, Chinese industrial development is no longer at the expense of environmental damage as compared to the preceding periods.

The education level has not yet played a significant role in promoting the efficient use of government expenditure on environmental protection. In China, educational resources are relatively scarce, culminating in the low-level education standards, which indirectly leads to insufficient knowledge on environmental protection awareness of citizens. However, with the continued balanced development of China, as well as the distribution and mutual support of educational resources among different regions in China, it is anticipated that the educational level of the current generation is likely to have a significant positive effect on the efficient utilization of the government expenditure on environmental protection.

\section{Conclusions and Policy Recommendation}

This study used the SBM super-efficiency model based on the unexpected output to measure the efficient use of the Government's financial, environmental protection expenditure. The study also measures the efficiency value in detail by analyzing the na- 
tional, regional, and provincial levels of EPEE to determine the changing trends in their mean values. Finally, a regression model is constructed to ascertain the influencing factors of the efficient utilization of government expenditure on environmental protection. The main conclusions derived from the study are enshrined as follows:

From an overall perspective of the study, the aggregate efficiency of utilization of the government environmental protection expenditure in the 30 selected provinces (municipalities and autonomous regions) in China has minimal fluctuation during the period 2013 to 2018, and the efficiency value has remained between 0.75 and 0.85 . Although the maximum utilization of government environmental protection expenditure has not been realized, the overall efficiency value has remained at the intermediate level; results obtained indicate that there is still room for improvement in the subsequent period. The regional level analysis indicated some differences between the eastern, the central, and the western regions. The efficiency value of the western region is greater than that of the central and the eastern regions, while the eastern region is slightly above the central region. Also, the provincial-level analysis indicated that most provinces had not reached an effective state of decision-making units for a prolonged period. The province with the highest efficiency value is Hainan, and the province with the lowest efficiency value is Heilongjiang. The two provinces have wide differences in geographical location and industrial development, resulting in a difference in efficiency values.

The analysis of the influencing factors also indicated a significant positive correlation between the regional economic development level and the efficiency of the government expenditure on environmental protection. The size of the population and urbanization level impact the efficiency value negatively, while the industrialization degree and population education level has no significant impact on the efficient use of the government expenditure on environmental protection.

In connection with the above conclusions, this study proposes the subsequent countermeasures and suggestions:

First, the Chinese Central Government, which is serving as the leader of the environmental protection team and the maker of all decisions, should fully consider the difference between the eastern and western regions and formulate appropriate policies and measures that would eliminate the one-size-fitsall phenomenon in China. Simultaneously, the local governments should implement relevant policies to suit the local conditions by implementing policy innovations on time without deviating from the guiding ideology of the Chinese Central Government to improve the efficiency of the local government expenditure on environmental protection. Also, supervision is key in carrying out any effective tasks. The environmental protection control department needs to be governed with a strict supervision system to ensure efficient utilization of resources. Studies have shown that environmental regulation mechanisms promote regional green technology innovation, improving the efficient utilization of government environmental protection expenditure (Guo et al., 2019). The Central Government should consider the series of challenges the regional supervision unit faces from a global perspective and implement a long-term development plan of supervision work with the rule of law. To ensure implementation effectiveness, responsibilities should be clearly defined, and the inspection of the performance of duties by local governments and their environmental protection agencies should be strengthened in China. Another factor worth consideration is to highlight the key functions of supervision and institute transformational measures from mainly checking enterprises to simultaneously monitoring and supervising the government officials. Further consideration should be geared towards the standardization of the supervision system and improving the supervision procedures through innovative supervision methods. Conversely, there should be openness and transparency in the process of supervision. Eventually, teamwork and platforms for deliberations should be instituted and strengthened to improve the quality of law enforcement for personnel and timely dissemination of information.

Second, it is suggested that the local governments should appropriately adjust the percentage of government expenditure on environmental protection efficiency based on performance. The empirical results of this study show that only $26.67 \%$ of the provinces have efficiency values greater than 1 , and the remaining $73.33 \%$ representing the other provinces have not fully utilized the government expenditure on environmental protection, and there is a phenomenon of redundant expenditure. Therefore, the provinces that have achieved greater efficiency are expected to reduce pollution emissions, improve the waste utilization rate and increase the greening in their areas as soon as possible without reducing environmental protection capital expenditure. In terms of the regions with low efficiency, the scale of the government expenditure on environmental protection should be reduced reasonably to improve efficiency through the application of the funds. When deciding the proportion of the environmental protection expenditure to be invested, the central and local governments should fully consider each province's local economic development level, population size, and urbanization level before final disbursement is implemented.

In other words, institutions should not blindly make huge investments because of the high level of economic development, nor reduce their investment owing to the small population size. The institutions should comprehensively consider several influenc- 
ing factors and rationally disburse the government expenditure. For example, Guangdong Province, which is an economically developed province, also has the characteristics of a large population and more migrant workers. Although it has invested a large number of financial grants to environmental protection funds annually, its efficiency is still second-tolast in line. The number of populations is a difficult factor to control in Guangdong Province because a large number of foreign workers are attracted to the place due to its standard of development. The large population size increases the environmental pressure and raises the problem of supervision in Guangdong Province. Further, Guangdong Province needs to strengthen its supervision policies and reduce government expenditure on environmental protection to upgrade its efficiency in using funds.

Third, environmental awareness is the embodiment of every citizen's comprehensive quality of life, which is highly related to the citizen's education level. The regression coefficient results obtained concerning the educational level and the efficiency of the government expenditure on environmental protection are positive. Although it is not significant, it demonstrates to a certain degree that the overall improvement of the educational level of citizens is conducive to the implementation of China's environmental protection policy. Emphasizing that if all the departments concerned in making decisions are to make better environmental protection policies, they should start with ideological education, strengthen the publicity of environmental protection, and make citizens consciously participate in environmental protection. Institutions can vigorously promote environmental protection public welfare policies; introduce the learning contents concerning environmental protection, garbage classification, and waste utilization into the classrooms of basic and secondary schools throughout China, and implement environmental protection propaganda work down to the grassroots level, and finally make every citizen realize that protecting the environment and resources of the nation is the duty of every citizen. If all individuals cultivate the habit of protecting their environment and agree to start from scratch, make joint efforts, and persevere, we can have clean water and blue sky for the current society and future generations in China and the entire globe.

\section{Funding}

This work is supported by the National Natural Science Foundation of China [grant number 7217407- 6 and $71974081]$

\section{Acknowledgements}

This study was supported by the Key Research Base of Universities in Jiangsu Province for Philosophy and Social Science Research Center for Green Development and Environmental Governance.

\section{Data Availability}

All data used are available and would be supplied upon request.

\section{References}

1. AGUILAR-HERNANDEZ G.A., DIAS RODRIGUES J.F., TUKKER A., 2021, Macroeconomic, social and environmental impacts of a circular economy up to 2050: A meta-analysis of prospective studies, Journal of Cleaner Production, 278, DOI: 10.1016/j.jclepro.2020.123421.

2. AHN T., CHARNES A., COOPER W.W., 1988, Some statistical and DEA evaluations of relative efficiencies of public and private institutions of higher learning, Socio-Economic Planning Sciences, 22(6): 259-269,

DOI: $10.1016 / 0038-0121(88) 90008-0$

3. AMANKWAH-AMOAH J., SYLLIAS J., 2020, Can adopting ambitious environmental sustainability initiatives lead to business failures? An analytical framework, Business Strategy and the Environment, 29(1): 240-249, DOI: 10.1002/bse.2361.

4. BIAO T.Q.W., 2012, Empirical Study on the Local Government's Financial Expenditure Efficiency and Its Influence Factors in China, Journal of Financial Research, 2.

5. CHARNES A., COOPER W.W., RHODES E., 1978, Measuring the efficiency of decision making units, European Journal of Operational Research, 2(6): 429-444.

6. CHENG C.; CHEN Z., 2017, Analysis of the efficiency of provincial governments' financial expenditure on environmental protection and its influencing factors, Statistics and Decision Making. 13: $130-132$.

7. CHENG G., 2014, Data envelopment analysis: methods and MaxDEA software, Intellectual Property Pub: Beijing, China.

8. DASGUPTA S., LAPLANTE B., WANG H., WHEELER D., 2002, Confronting the environmental Kuznets curve, Journal of Economic Perspectives, 16(1): $147-168$

9. FARRELL M. J, 1957, The Measurement of Productive Efficiency, Journal of the Royal Statistical Society. Series A (General), 120(3): 253290.

10. GUO Q., ZHOU M., LIU N., WANG Y., 2019, Spatial effects of environmental regulation and green credits on green technology innovation under lowcarbon economy background conditions, International Journal of Environmental Research and Public Health, 16(17): 3027.

11. HALKOS G.E., PAIZANOS E.A., 2013, The effect of government expenditure on the environment: An empirical investigation, Ecological Economics, 91: 48-56.

12. HONGGUO Y., 2015, Fiscal self-sufficiency environmental protection tax and fee allocation and local government environmental protection expenditure efficiency-an empirical analysis based on DEA-Tobit panel model, Research of Finance and Accounting, 10: 14-18

13. HUANG G., 2011, Research on the efficiency of local government finance for environmental protection, Journal of Guangxi University for Nationalities (Philosophy and Social Science), 
33(06): 161-164.

14. KRAJEWSKI P., 2016, The impact of public environmental protection expenditure on economic growth, Problemy Ekorozwoju/ Problems of Sustainable Development, 11(2): 99-104.

15. KUAI P., YANG S., TAO A., ZHANG S., KHAN Z.D., 2019, Environmental effects of Chinese-style fiscal decentralization and the sustainability implications, Journal of Cleaner Production, 239: 118089 , DOI:10.1016/j.jclepro.2019.118089.

16. PETROVIĆ P., LOBANOV, M.M., 2020, The impact of $\mathrm{R} \& \mathrm{D}$ expenditures on $\mathrm{CO}_{2}$ emissions: Evidence from sixteen OECD countries, Journal of Cleaner Production, 248, DOI: 10.1016/j.jclepro.2019.119187.

17. SIEBERT H., SIEBERT H., 1998, Environmental Quality as a Public Good, Economics of the Environment: 59-93,

DOI: 10.1007/978-3-662-11594-7_5.

18. SUN K., SUN L., 2016, Research on the efficiency of fiscal environmental protection expenditure based on input-output ratio - DEA-Tobit analysis based on panel data of prefecture-level cities in Jilin province, Taxation and Economy, 05: 101-610.

19. TONE K., 2001, A slacks-based measure of efficiency in data envelopment analysis, European Journal of Operational Research, 130(3): 498509.

20. TONE K., 2002, A Slacks-Based Measure of SuperEfficiency in Data Envelopment Analysis, European Journal of Operational Research, 143: 32-41, DOI: 10.1016/S0377-2217(01)00324-1.

21. WANG B.; LIU J.A., 2011, Study on the Efficiency Evaluation of Financial Expenditure on Environmental Management in Chinese Local Cities, Journal of Guangxi University for Nationalities (Philosophy and Social Science), 18(4): 71-76.

22. WANG Q., LI C., 2018, Study on the Efficiency Evaluation and Influencing Factors of China's Fiscal
Environmental Protection Expenditure. East China Economic Management, Sustainable Cities and Society, 32(07), p. 102-109.

23. WANG P., 2018, Analysis of the efficiency of public environmental expenditure based on data envelopment analysis (DEA)-Tobit model: evidence from Central China, Nature Environment and Pollution Technology, 17(1): 43-48.

24. XU M., HU W.Q., 2020, A research on coordination between economy, society and environment in China: A case study of Jiangsu, Journal of Cleaner Production, 258: 120641, DOI: $10.1016 /$ j.jclepro.2020.120641.

25. YONGBIN G., 2015, Efficiency evaluation of China's local government environmental protection expenditure based on DEA model, Journal of Chongqing Normal University (Edition of Social Sciences), 4: 73-80.

26. ZAFAR M.W., SHAHBAZ M., HOU F., SINHA A., 2019, From nonrenewable to renewable energy and its impact on economic growth: The role of research \& development expenditures in Asia-Pacific Economic Cooperation countries, Journal of Cleaner Production, 212: 1166-1178, DOI: 10.1016/j.jclepro.2018.12.081.

27. ZHANG J., QU Y., ZHANG Y., LI X., MIAO X., 2019, Effects of FDI on the efficiency of government expenditure on environmental protection under fiscal decentralization: a spatial econometric analysis for China, International Journal of Environmental Research and Public Health, 16(14): 2496.

28. ZHAO J., LI S., WANG J., 2020, Evaluation of the utilization efficiency of financial environmental protection funds in China: A win-win perspective of economy and environment, Economic and Management Research, 41(01): 21-35.

29. ZHU H., FU Q., WEI Q., 2014, Calculation of efficiency on environmental expenditure and study on influential factors, China Popul. Res. Environ, 24: 91-96. 